\title{
Public Policies to Be Implemented to Encourage the Use of Renewable Energy Sources in the Rural Area of Paraná
}

\author{
Alexandre G. Batista ${ }^{1 *}$ \\ https://orcid.org/0000-0002-7419-4544 \\ Roberto C. Betini ${ }^{2}$ \\ https://orcid.org/0000-0003-1817-6330 \\ Maria Luiza E. Bareta ${ }^{1}$ \\ https://orcid.org/0000-0001-8448-6260
}

\author{
Álvaro A. Sandim ${ }^{1}$ \\ https://orcid.org/0000-0002-7124-2635
}

\author{
Luiz A. Pepplow ${ }^{1 *}$ \\ https://orcid.org/0000-0001-8124-1778
}

1Universidade Tecnológica Federal do Paraná, Electrical Engineering, Curitiba, Brazil; 2 Universidade Tecnológica Federal do Paraná Electrotechnology Department, Curitiba, Brazil

Received: 2018.11.05; Accepted: 2019.07.26.

* $\quad$ Correspondence: alvaroafonso10@gmail.com; Tel.: +55-41-984635397 (A.A.S); alejjunior@gmail.com; (A.G.B); mlbareta1460@gmail.com; (M.L.E.B); betini@utfpr.edu.br; (R.C.B); luizpepplow@utfpr.edu.br; (L.A.P)

\section{HIGHLIGHTS}

- 3 public policies wore proposed based on the research, those being feed-in tariff, Market Premium and accelerated depreciation

\begin{abstract}
Around the world there's a rising interest in the installation of renewable energy sources due to their ecological, economical, political and social advantages. In this article is studied specifically the case of the incentive towards the installation of these sources in the state of Parana's rural area, where they wouldn't just be ecologically interesting, but also would help the improvement on the living conditions of the rural producers, promote income distribution and would cause an increase on the power supply, this way reducing the tariff. However, the problem arises in the acquisition of the energy generator, since even though they are interesting for the rural producers, these sources are majorly too expensive and end up being beyond their purchasing power. Based on that, this article brings a selection of public policies that could make the use of these sources viable in the rural area of the state, based on the experiences of other countries who face or have faced in the past similar difficulties, like China or India, and countries who have become reference in the matter, like Germany.
\end{abstract}

Keywords: renewable energy, public policies, rural areas 


\section{INTRODUCTION}

Energy and ecological security are first-rate problems faced by our global economy [12]. Currently we live in Paraná a situation of an energy system based almost entirely on generation by hydroelectric plants with $89 \%$ of our energy matrix being occupied by this type of source [4], but hydroelectric plants, mainly large ones such as Itaipu, cause significant amounts of environmental damage by both greenhouse gas (GHG) emissions and the damage to the entire region that needs to be flooded, killing local biodiversity. In addition to this problem, there is also problem caused by the great distances that often separates the substations and the rural consumers, that way causing losses in the transmission lines as well as loss of quality of the energy delivered to these consumers. Thus, the importance of the expansion and creation of new micro/mini-generation units in the rural environment of the state of Paraná that operate from renewable sources of energy.

\section{THE PROBLEM}

Regarding hydroelectric plants, we have the issue of its not so sustainable generation system, which is the subject of the BALCAR project, executed by Eletronorte, Furnas and Chesf, under the technical supervision of COPEL. The objective of the project was to create a document with the data derived from the analysis and modeling carried out from measurements of greenhouse gas flows and related variables obtained in 44 field campaigns between 2011 and 2012 in 11 hydroelectric dams, between them Itaipu and Segredo, both located in Paraná. The project document includes the GHG emissions and removals of each of the hydroelectric plants visited measured in tonnes per day of $\mathrm{CO} 2$, therefore, measurements involve $\mathrm{CH} 4$ and other greenhouse gases that, in the presentation of the data, are multiplied by a conversion factor that takes into account the magnitude of the greenhouse effect of each gas compared to CO2. Thus, in Itaipu, was recorded an emission balance of the equivalent to $645.12 \mathrm{t} /$ day of $\mathrm{CO} 2$, while a balance of the equivalent to the emission of 28.86 t/day of $\mathrm{CO} 2$ was recorded in Segredo. For comparison purposes, according to the National Emissions Registration System (SIRENE), emissions per day of the Brazilian industrial sector in 2010 were $246,430 \mathrm{t} /$ day of CO2 equivalent. Thus, it is evident that, even though hydroelectric plants cause less emissions than thermoelectric plants, they still cause a significant amount of GHG emissions.

From this, it is clear the importance of encouraging the use of renewable energy sources in rural areas, including alternative ways to exploit hydroelectric potential. To do so, it is necessary to have governmental measures adopted for this purpose, since this is a matter of interest to the concessionaire (since it reduces the losses in the lines as well as problems with energy quality), as well as to the government and society (in addition toreducing the environmental impact already mentioned, there is also the possibility of an additional source of income for producers who sell the excess of their generation).

\section{PUBLIC POLICIES CURRENTLY ON EFFECT}

One of the definitions of public policies used by the National School of Public Administration (ENAP) in the collection of public policies, defines them as "a system of public decisions aimed at actions or omissions, preventive or corrective, aimed at maintaining or modifying the reality of one or several sectors of social life, through the definition of objectives and strategies of action and the allocation of the resources necessary to achieve the established objectives", therefore the objective here is the use of state power to fulfill the agenda demanded by society through a series of governmental measures.

Still according to the ENAP, each public policy goes through seven stages:

1) The agenda stage, a set of social facts are now considered a public issue because of their implications and now justify public intervention.

2) The elaboration, which consists of the delimitation of the problem, determination 
of possible solutions and evaluation of the costs and effects of each of them.

3) The formulation, which selects the alternative considered most convenient and defines its objectives and other details.

4) The implementation, consisting of the planning and organization of the administrative apparatus and the human, financial, material and technological resources necessary to execute a policy

5) Execution, which is the set of actions aimed at achieving the goals set by the policy. It is to put into practice the policy.

6) The monitoring, which is the systematic process of supervising the execution of an activity, which aims to provide the necessary information to introduce any corrections in order to ensure the achievement of the established objectives.

7) The evaluation, which consists of the measurement and analysis, a posteriori, of the effects produced.

In the case studied, public policies have already been implemented, which have taken the form of several resolutions of the National Agency and Electric Energy (ANEEL) and federal laws. The following is a list of the most important laws and resolutions in this field currently in force:

1) Federal Law No. 9.074 of July 7,1995 , which states that the use of hydraulic potentials equal to or less than $1,000 \mathrm{~kW}$ and the installation of thermoelectric plants with a power of $5,000 \mathrm{~kW}$ or less are exempt from concession, permission or authorization. and should only be communicated to the granting authority. Article 10 gives ANEEL the power to declare the public utility, for the purposes of expropriation or the institution of administrative easement, of the areas necessary for the deployment of the concessionaires, permittees and other authorized institutions installations,

2) Federal Law 9.427, of December 26, 1996, which includes several provisions that favor alternative renewable sources. Article 26 establishes discounts on transmission and distribution tariffs of at least $50 \%$ for small hydroelectric plants, for hydroelectric projects with a capacity of $1,000 \mathrm{~kW}$ or less and for those based on solar, wind, biomass and qualified cogeneration whose power injected into transmission or distribution systems is less than or equal to $30,000 \mathrm{~kW}$. It also exempts SHPs from the payment of financial compensation for the exploitation of water resources for the purposes of electricity generation. In addition, it establishes that SHPs, hydroelectric projects with a capacity of $1,000 \mathrm{~kW}$ or less and those based on solar and wind sources, biomass and qualified cogeneration whosepower injected into transmission or distribution systems is less than or equal to $50,000 \mathrm{~kW}$ may trade electricity with a consumer or set of consumers, whose load is greater than or equal to $500 \mathrm{~kW}$, if met by the National Interconnected System - SIN, or greater than or equal to $50 \mathrm{~kW}$ when the consumer or set of consumers are located in areas served by isolated systems.

3) Federal Law No. 9.648, of May 27, 1998, provides that the generation of electricity from SHPs or from wind, solar, biomass and natural gas sources, which will be implemented in an isolated electrical system and replaces the thermoelectric generation that uses petroleum derivatives or moves its operation to meet the market growth may receive resources from the Fuel Consumption Account (CCC), intended to reimburse the additional costs of electricity generation in isolated systems. It should be noted here that the wording of item I of $\S 4$ of this law did not include among the beneficiaries of the subrogation of the right to receive $\mathrm{CCC}$ funds hydroelectric projects with a power of $1,000 \mathrm{~kW}$ or less. 
4) Federal Law No. 10.847, of March 15, 2004, which authorized the creation of the Energy Research Company - EPE, it is noteworthy that, among the competencies of this public company, are various attributions related to alternative sources of energy, such as identifying and quantify the potentials of energy resources; develop studies of social impact, technical-economic and socio-environmental feasibility for the projects of electricity and renewable sources; develop studies to assess and increase the use of energy from renewable sources; prepare and publish inventory studies of the potential of electricity from alternative sources.

5) ANEEL Normative Resolution No. 077/2004, which establishes procedures related to the reduction of tariffs for the use of electric transmission and distribution systems for hydroelectric generation projects, characterized as Small Hydroelectric Power Plants, and those with solar, wind, biomass or qualified cogeneration with an installed capacity of $30,000 \mathrm{~kW}$ or less.

6) ANEEL Normative Resolution No. 109/2004, establishes the Electric Energy Commercialization Convention, establishing the structure and the functioning of the Electric Energy Commercialization Chamber - CCEE

7) ANEEL Normative Resolution No. 482/2012, which "establishes the general conditions for access to distributed micro-generation and mini-generation to the electric power distribution systems, the electric power compensation system, and other measures. ". In the text of the norm the compensation system is regulated, where the energy injected into the system will be converted into energy credits for use in the same month or up to 60 subsequent months in a unit on the same holder.

8) ANEEL Normative Resolution No. 506/2012, which "Establishes the conditions for access to the distribution system through connection to facilities owned by the distributor and makes other arrangements. ". The text of the norm regulates the trading of energy so that the energy can be traded in the regulated contracting environment (energy auctions) or in the free contracting environment (bilateral contracts with free / special or trading clients, or with the settlement in the shortterm market - PLD).

In addition there are also government programs to encourage the use of renewable sources with the main ones listed below from [15]:

1) Transmission Systems Usage Tariff (TUST) and Distribution Systems Usage Tariff (TUSD) Discounts:

a) $80 \%$ Discount on Transmission Systems Usage Tariff (TUST) and Distribution Systems Usage Tariff (TUSD) for ventures whose power injected into the transmission or distribution systems is less than or equal to $30,000 \mathrm{~kW}$ and which come into operation until December 31,2017; The discount is now $50 \%$ from the 11 th year of operation of the solar plant and for projects that start operating from January 1, 2018.

2) Direct Selling to Consumers:

a) Permission for solar and other alternative power generators with injected power of less than $50,000 \mathrm{~kW}$ to trade electricity without intermediation from distributors with special consumers with a load between $500 \mathrm{~kW}$ and $3,000 \mathrm{~kW}$.

b) In the acquisition of energy, special consumers benefit from a discount on TUSD, which encourages the replacement, as an energy supplier, of the distributor by the alternative source generator.

3) Agreement No. 101, of 1997, of the National Council of Finance Policy (CONFAZ), ICMS exempt from transactions involving various equipment for the 
generation of electricity by photovoltaic cells and wind projects.

Thus, we see that we already have more than 20 years of accomplishments and political achievements to encourage the use of renewable energy sources throughout Brazil. However, according to data provided by COPEL, the average monthly consumption in the rural area that served by the concessionaire is $279.552 \mathrm{MWh}$, while $202.308 \mathrm{kWh}$ were injected into the network by micro / mini generation units, from the installed capacity of $34.734 \mathrm{~kW}$ of solar energy, $6.399 \mathrm{~kW}$ of biomass energy, $500 \mathrm{~kW}$ of SHPs and $33,5 \mathrm{~kW}$ of wind energy. The rural consumption represents approximately $17.5 \%$ of the state's total, while the energy injected by these units represents less than $0.1 \%$ of rural consumption. Therefore, it is evident that, although several advances have already been made in this area, there is still much room for growth, considering that, according to [13], the state of Paraná has a generation potential of $30 \mathrm{TWh} /$ year from biomass, $10 \mathrm{TWh}$ / year for electric generators, up to $49 \mathrm{TWh} /$ year for photovoltaic generation and $74 \mathrm{TWh} /$ year for hydroelectric generators, showing here that one cannot rule out the various types of hydro, mainly through Small Hydroelectric Plants (SHPs).

\section{PUBLIC POLICIES IN OTHER COUNTRIES}

Once presented the current situation of renewable energy sources in Paraná, as well as the process of creation and implementation of public policies, the next step is a study of public policies implemented abroad, mainly in reference countries, such as Germany.

In Germany, the Renewable Energy Sources Act is currently in force, a decree aimed at enabling energy supply to develop in a way that reduces environmental impact, reduces energy supply costs for the economy, conserves fossil energy resources. and promote the development of renewable energy generation technologies [5]. This decree was made with the intention of increasing the proportion of energy generated from sustainable sources from the current $36.1 \%$, according to the website "Agora Energiewende", to between $40 \%$ and $45 \%$ by 2020 . To this end, a system of direct sale of energy similar to our Electric Energy Trading Chamber (CCEE) was implemented, where producers can hold agreements and auctions directly with interested consumers, and the difference between the value of energy sold by the producer and its market value is passed on to him by the concessionaire under the name "Market Premium". This direct selling system supported approximately 112TW of renewable energy in 2015 according to the "Fifth Monitoring Report 'The Energy of the Future' 2015". With these measures Germany managed to increase the share of renewable energy sources in its energy matrix by $31.8 \%$ between 2000 and 2017, demonstrating the effectiveness of these policies in conjunction with multiple information programs for the population about the possibilities and benefits of these sources. .

In addition to Germany, it is interesting to look at countries with a economic situation more similar to Brazil, for example China, who adopted the feed-in tariff system, which are tariffs established with long-term contracts, generally over 15 years, for energy generationby renewable sources, regardless of its use (self-consumption or for export). The tariff value (in monetary units per $\mathrm{kWh}$ ) is established based on the generation cost, depending on the source, type of installation, etc. The incentive for energy production comes from the fact that the amount paid for the energy injected into the grid is greater than the energy purchased from the distributor. In addition, the country also announced in March this year its plan to set up a compulsory renewable energy quota system for agents including large consumers and energy transmission, distribution and sale companies. This system is characterized by the obligation of certain companies and entities to have a portion of their energy from renewable sources, which may be produced by these agents or bought in the energy market. These quotas are controlled through a system of Renewable Energy Certificates (RECs) issued for each MWh of energy produced from renewable sources. By the end of the year, agents with insufficient RECs are required to purchase replacement certificates, which are regulated by the National Development and Reform Commission and have their prices proposed by the power utilities to reach the quota. These quotas vary 
from province to province and also vary with the years.

Another interesting country to look at along these lines is India, where an accelerated depreciation system was introduced in 2014 as a fiscal incentive. This policy is based on a reduced tax on revenue received from certain renewable energy sources such as solar panels and biogas. This reduction in taxation results from a reduction in the real value of revenue at the time of calculating what would be similar in Brazil to income tax, in India's case the calculation is based on the amount of revenue minus the value of the generator multiplied by $80 \%$ (in this case the depreciation is $80 \%$ ). For example, if a producer installs a 1 million dollars biodigester that earned him 1.5 million in the first year in a $30 \%$ tax situation, we have:

$$
\operatorname{Tax}=0.3^{*}(1.5-0.8 * 1)=0.21 \text { million }
$$

Thus increasing this producer's profit margin by 0.24 million in its first year. This way the use of these sources is encouraged to help improve income especially in the early years where the financial difficulty of purchasing these sources is greatest. Following implementation, renewable energy generation in India increased from 70,560 GWh in 2014 to 90,748 GWh in 2016 according to the International Renewable Energy Agency (IRENA) survey.

\section{GOALS}

From the data analyzed, the intention is to propose possible public policies that could lead to an improvement, ecologically speaking, in the energy matrix of Paraná, an increase in energy supply in the countryside, a better quality of life for rural producers, an increase in possibility of production of these producers given the increase in their purchasing power for investments, which also entails an increase in the labor supply in the field, since with the increase in their production these producers will need more labor in their properties.

\section{MATERIAL AND METHODS}

To achieve these objectives, a survey of other articles that studied the area was used, as well as a study of the policies in force in the selected countries. Finally, a parallel with the situation in the state of Paraná was raised to determine which policies would be useful in our context.

\section{RESULTS}

With the survey carried out, it remains to present the public policies that were selected and how they would be applied in Paraná.Starting with the feed-in tariff, applied in India, Germany and practically the entire European Union. This policy in Parana could be used to encourage renewable energy installations, especially in the case of SHPs and solar panels (which have the highest generating potential in the state according to [13]), since several rural producers have an interesting potential for SHPs that are wasted as well as a great untapped solar potential.

Following is the accelerated depreciation implemented in India, Argentina, Indonesia and several others. This measure, as well as the feed-in tariff, is very interesting in the Parana context of great untapped potential, where there is a possibility that a large number of new sources can be installed, as it reduces the initial expenses of the producers who will use these sources to supplement their income and accelerate the payback time of the investment.

Another proposed policy, also applied in Germany, is that Market Premium, wich could be implemented in a tailored manner. Firstly, it is possible to implant this system in CCEE so as to pass on to the producer who sells his energy for less than the market value something around $50 \%$ of this difference, thus not only encouraging more producers to participate in this market, but also maintaining affordable energy that encourages the 
growth of this market as a whole. In addition, it is possible, for non-CCEE producers, to update the credit energy compensation system regulated by ANEEL Normative Resolution No. 482/2012, in order to offer the option of receiving a percentage of these credits in cash, for example something around $20 \%$. Thus, producers who do not intend to enter the CCEE and yet have a higher energy production than their consumption may have a source of income from their renewable energy sources without relying on deals involving arrangements with other producers to create electricity consortia or cooperatives as provided by Copel in the shared generation system.

Finally, we have the quota system, applied in China and Chile for example, which in the case of Paraná would depend on a national process of creating quotas and stipulating values for RECs, not to mention that at the short term situation of few producing agents, as seen in analyzing the proportion between energy produced from renewable sources in rural areas and consumption in this region, this measure would not be effective. Therefore, it is suggested to implement this policy in a few more years, when renewable production has a larger participation in the energy market not only in Paraná but also in the whole country.

\section{DISCUSSION}

These proposals characterize a work in progress, as they only direct the work of a forthcoming research work that seeks to determine which of these proposals are most interesting to the agents involved in this discussion as well as the definition of details such as the duration of the feed-in tariff agreements.

Still, it would be interesting to compare this work with others on this subject, but in the Paraná ambit there are few works that discuss public policies for renewable sources per se, since the vast majority carry out feasibility and generating potential studies, so much so that the source of this research for the public policy proposals came from other countries.

\section{CONCLUSION}

Once the research was finished, it was concluded that Paraná has a potential to expand the installed capacity of renewable energy sources, as presented above. Therefore it is necessary and possible to create new public policies to encourage the installation of these sources, as well as updating of existing policies.

Thus, leading to the proposal of 3 new governmental measures as well as the proposal to update ANEEL Normative Resolution No. 482/2012. Finally, we discussed theneed to move this work forward by conducting further study to define the details of these policies so that they may one day be implemented.

Acknowledgments: The authors thank UTFPR (Federal Technological University of Paraná) for the infrastructure offered for the development of this research, and COPEL for the support provided through the email exchange and the data provided on their site. This research was part of the R\&D project 2866-0464/2017 "Metodologia Para Análise, Monitoramento E Gerenciamento Da Gd Por Fontes Incentivadas."

\section{REFERENCES}

1. Tiepolo, G. et al. Comparação entre o potencial de geração fotovoltaica no Estado do Paraná com Alemanha, Itália e Espanha. In: Congresso Brasileiro De Energia Solar, 5. 2014, Anais.Recife, 2014.

2. Pereira, Thulio Cícero Guimarães. Energias renováveis: políticas públicas e planejamento energético. Edição digital. 2014.2 Available online:<http://repositorio.utfpr.edu.br:8080/jspui/handle/1/942> (accessed on 5 September 2018).

3. Franco, Cezar Augusto de Oliveira. Sistema Elétrico Brasileiro e Marco Regulatório das Energias Renováveis. 2016.

4. MME. Matrizes Energéticas Estaduais. Ano de referência: 2015. ed. 02. 21 de novembro de 2016.

5. Alemanha, Renewable Energy Sources Act (EEG 2017). 2017.

6. Amelang, Sören. Renewables cover about $100 \%$ of German power use for first time ever. 
2018.

Available

online:

$<$ https://www.cleanenergywire.org/news/renewables-cover-about-100-german-power-use-fi rsttime-ever>. (accessed on 09 September 2018).

7. Chen, Yiran ;Chan, Hei Tung; Feng, Shihang; Lau, Yu Ho; Tse, Wai Hong; Van Lierde, Robin Maggy P. Feed-in tariff for renewable energy in Germany and Hong Kong. 2017. Available online: <http://dspace.cityu.edu.hk/handle/2031/110>. (accessed on 12 September 2018)

8. IEA. Renewable Electricity Quota and Assessment Method (Draft for Opinions). 2018. Available online:

<https://www.iea.org/policiesandmeasures/renewableenergy/?country=China>. (accessed on 13 September 2018).

9. Santhanam, Narasimhan. What is Accelerated Depreciation? What Benefits does it provide to a Solar Power Plant Developer? 2015. Available online:

<http://www.solarmango.com/ask/2015/10/08/what-is-accelerated-depreciation-what-benef itsdoes-it-provide-to-a-solar-power-plant-developer/>. (accessed on 13 September 2018).

10. Irena. Renewable Energy Statistics 2017. 2017. Available online:

<http://www.irena.org/publications/2017/Jul/Renewable-Energy-Statistics-2017>. (accessed on 13 September 2018).

11. lisd .Case Study India's Accelerated Depreciation Policy for Wind Energy. 2015. Available online: <https://www.iisd.org/sites/default/files/publications/india-accelerated-depreciation-policy-w ind-energy-case-study.pdf>. (accessed on 13 September 2018).

12. Betini, Roberto Cesar. Estratégias De Pesquisa E Desenvolvimento Para A Redução Do Uso De Combustíveis Fósseis. 2014.

13. Tiepolo, G. Et Al. Estudo Do Potencial De Participação Das Fontes Renováveis De Energia Na Matriz Elétrica Do Estado Do Paraná. In: Congresso Brasileiro De Planejamento Energético. 2014.

14. Freitas, Bruno M. R. Et Hollanda, Lavinia. Micro E Minigeração No Brasil: Viabilidade Econômica E Entraves Do Setor. 2015.

15. Silva, R. M. Energia Solar: Dos Incentivos Aos Desafios. Texto Para Discussão No 166. Brasília. Senado Federal, 2015

(C) (1) $\$$ C. $_{\text {NC }} 2018$ by the authors. Submitted for possible open access publication
under the terms and conditions of the Creative Commons Attribution (CC
BY NC) license (https://creativecommons.org/licenses/by-nc/4.0/). 